\title{
Konaklama İşletmelerinin Yeşil Yıldız Uygulamaları Kapsamında Çevreye Duyarlılığının Değerlendirilmesi
}

\section{Evaluation of Environmental Sensitivity of Hospitality Industry within the scope of Green Star Applications}

\author{
Arş. Gör. Mehmet ERTAŞ \\ Pamukkale Üniversitesi \\ Turizm Fakültesi \\ E-posta: mertas29@gmail.com \\ Orcid Id: 0000-0003-4396-5104
}

\author{
Arş. Gör. Burçin KIRLAR CAN \\ Pamukkale Üniversitesi \\ Turizm Fakültesi \\ E-posta: burcinkirlar@gmail.com \\ Orcid Id: 0000-0003-0819-3014
}

Arş. Gör. Hülya YEŞiLYURT

Adıyaman Üniversitesi

Turizm Fakültesi

E-posta: hyesilyurt@adiyaman.edu.tr

Orcid Id: 0000-0002-9991-2557
Prof. Dr. Nilüfer KOÇAK

Dokuz Eylül Üniversitesi

İzmir Meslek Yüksekokulu

E-posta: nilüfer.kocak@deu.edu.tr

Orcid Id: 0000-0002-9299-4553

\section{Öz}

$\mathrm{Bu}$ araştırmanın amacı, yeşil yıldız belgeli konaklama işletmelerinin çevreye duyarlılığını web siteleri üzerinden inceleyerek bu uygulamalardan hangilerine daha fazla vurgu yaptıklarını belirlemektir. Yeşil yıldız belgeli 309 konaklama işletmesi araştırmanın evrenini oluşturmaktadır. Araştırmada Kültür ve Turizm Bakanlığı'nın belirlediği çevreye duyarlılık kriterleri temel alınmıştır. Veri toplama yöntemi olarak doküman incelemesi kullanılırken, verilerin analizinde içerik analizi ve betimsel analiz tekniği kullanılmıştır. İçerik analizi sonucunda yedi temel ve 12 alt kategori elde edilmiştir. Araştırma sonucunda, konaklama işletmelerinin büyük çoğunluğunun yeşil yıldız belgesi ve çevre yönetimi ile ilgili uygulamaları hakkında bilgi vermediği ortaya çıkmıştır. Yeşil yıldızlı konaklama işletmeleri web sitelerinde en çok çevreyle ilgili sahip oldukları ödül ve sertifikalara yer vermektedir. Çevre politikası, atıkların değerlendirilmesi, personel ve misafir eğitimi ile enerji tasarrufu en fazla üzerinde durulan diğer konular arasındadır.

Anahtar Kelimeler: Çevre Yönetim Sistemleri, Yeşil Yıldız, Çevreye Duyarlılık, Konaklama İşletmeleri, Web Siteleri.

\begin{abstract}
The main purpose of this research is to examine the environmental sensitivity of green star hotels on their web pages and to clarify the most emphasized applications. The population of the research includes 309 hotels which have green star certification. The research is based on the environmental sensitivity criteria determined by the Culture and Tourism Ministry. Document analysis was used as a method of data collection and content analysis and descriptive analysis were used for data analysis. As a result of the content analysis, seven categories and 12 subcategories were obtained. As a conclusion, the majority of hotels do not provide information on green star certificate and environmental management related applications on their web pages. Awards and certificates are the most frequently used environmental topics on the web pages of green star hotels. Environmental policy, disposing of waste, personnel and customers training, and energy conservation are among the other most emphasized applications.
\end{abstract}

Key Words: Environmental Management Systems, Green Star, Environmental Sensitivity, Hospitality Industry, Web Pages. 


\section{Giriş}

Doğal ve kültürel çevrenin turistler için başlıca çekim unsuru olması, çevresel etmenlerin turizmi etkilemesi ve turizmin çevre üzerinde yarattığı etkilerden dolayı turizm ve çevre arasında karşılıklı bir ilişki bulunmaktadır (Kahraman ve Türkay, 2014). Turizm türlerinin ortaya çıkmasında, talebin artmasında, turizmin yılın tüm dönemlerine yayılmasında ve elde edilen gelirin artmasında hem fiziki hem de toplumsal çevre önemli bir yere sahiptir (Şanlı̈̈z-Özgen ve diğ., 2016). Doğal ve kültürel çevrenin gelecekte de çekiciliğini devam ettirebilmesi için turistik işletmelerin çevreyle uyumlu hale gelmesi ile birlikte ülkelerin turizmin ekonomik faydalarından daha fazla pay alması beklenmektedir (Usta, 2009). Ancak son yıllarda tüketim hızının ve turizm hareketliliğinin artması, turizm sektöründeki kaynak kullanımını olumsuz etkilemekte ve çevreye verilen zararı arttırmaktadır. Bu zararın farkına varan işletmeler ve tüketiciler de çevre konusunda daha duyarlı davranmakta, kaynakları koruyabilmek ve zararı en aza indirebilmek için çeşitli önlemler almaya çalışmaktadır.

Günümüzde değişen turist profiline paralel olarak, otel rezervasyonlarının büyük çoğunluğunun internet üzerinden yapılması konaklama işletmelerinde internet teknolojileri kullanımının pazarlama açısından bir zorunluluk haline geldiğini ortaya koymaktadır (ITB, 2016). Geleneksel dağıtım kanalları yerine doğrudan oteller üzerinden rezervasyon yaptıran turist sayısının gün geçtikçe artması, konaklama işletmelerinin yönetim biçimlerini değiştirmektedir. Bu bağlamda konaklama sektöründe internetin doğrudan dağıtım aracı olarak öneminin giderek artması ile etkili web sitelerinin geliştirilmesi ve korunması işletme başarısında kritik rol oynamaktadır (Jeong ve diğ., 2003).

Çevre bilinci ve çevre dostu otel algısı rezervasyon kararlarında ve konaklama işletmelerinde kalış sürelerinde etkili olmaktadır. Tüketiciler çevreye zararı olmayan ürünleri tercih etmekte ve işletmeleri de bu yönde stratejiler geliştirmeye zorlamaktadır. Dünya çapında kendisini çevreci olarak tanımlayan, bilinçli olarak çevre dostu tesisleri tercih eden ve çevre dostu hizmetlere daha fazla para ödemeye gönüllü olan yaklaşık 43 milyon turist olduğu söylenmektedir (Machaira ve diğ., 2012). TripAdvisor (2012) tarafından 700'ün üzerinde katılımcı ile gerçekleştirilen araştırmanın sonuçları, Amerikalı turistlerin \%71'inin bir önceki yıla göre daha fazla çevre dostu tatil planladıklarını ve yarısının da çevre dostu konaklama için daha fazla para harcama eğiliminde olduklarını göstermiştir. Gil ve diğerleri (2001) de proaktif çevresel yönetim anlayışına sahip otellerin diğer otellere kıyasla yıllık karlılık ve doluluk oranlarında üstünlüğe sahip olacaklarını ortaya koymaktadır. Yeşil pazarlama kapsamındaki araştırmalar, işletmelerin kurumsal imajına güç kattığı ve tüketicilerin algısındaki tercih edilebilirliği daha da arttırdığını ortaya koymaktadır (Atay ve Dilek, 2013). Bu bağlamda konaklama işletmelerinin çevreye duyarlı uygulamalarını bir pazarlama aracı olarak kullanmaları ve web sitelerinde buna yer vermeleri oldukça önem taşımaktadır.

Yeşil yıldız belgeli konaklama işletmelerinin çevreye duyarlılığını web siteleri üzerinden incelemek ve bu uygulamalardan hangilerine daha fazla vurgu yaptıklarını belirlemek amacı ile yürütülen bu araştırma, dört bölümden oluşmaktadır. Illk bölümde kavramsal çerçeve başlığı altında turizm ve çevre ilişkisi ile çevre yönetim sistemleri hakkında alanyazın taramasına yer verilmiştir. İkinci bölümde elde edilen verilerin analizine yönelik araştırma yöntem ve teknikleri açıklanmıştır. Üçüncü bölümde toplanan verilerin nitel araştırma teknikleriyle analiz edilmesi sonucu ortaya çıkan bulgular sunulmuştur. Son olarak tartışma ve sonuç bölümünde araştırmadan elde edilen bulgular yorumlanarak benzer çalışmalarla karşılaştırılmış ve konaklama işletmelerine yönelik öneriler ortaya konmuştur. 


\section{Kavramsal Çerçeve}

\subsection{Turizm ve Çevre İlişkisi}

Doğal ve yapay kaynakları önemli düzeyde kullanan sektörlerin başında gelen turizm, çevreye ciddi zararlar vermektedir (Gössling, 1999; Giritlioğlu ve Güzel, 2015). 1990'lı yıllar itibarı ile artan çevre hassasiyeti ve çevre koruma ile ilgili mücadeleler karşısında hükümet politikaları ve tüketici tercihleri yeniden şekillenmeye başlamış, işletmeler de bu duruma tepkisiz kalmayarak çevreye daha duyarlı hale gelmeye çaba göstermiştir (Johri ve Sahasakmontri, 1998). Turizm işletmelerinin çevreye duyarlı uygulamaları benimsemelerinin nedenleri arasında yasal düzenlemeler, politik açıdan kamu kurumları ile iyi ilişkiler kurma, çevreyi korumayı yönetim felsefesi olarak benimseme/etik, sahip olduğu fiziksel olanakları koruma, maliyet faktörleri, rekabet unsurları, kamuoyu baskıları, estetik kaygılar, çevreye duyarlı tüketici sayısının artması ve müşteri tatmini sağlama yer almaktadır (Berry ve Rondinelli, 1998; Foster ve diğ., 2000).

Konaklama işletmeleri de faaliyetlerinin doğası gereği çevresel problemlere neden olan önemli endüstrilerden birisi olarak kabul edilmektedir (Erdogan ve Baris, 2007; Ham ve Han, 2013). Günümüzde turistler daha eğitimli, çevresel ve kültürel farkındalığı daha yüksek, çevre kalitesine ve korunmasına önem veren, doğaya yönelen, yeni deneyimler arayan ve daha fazla etki gücüne sahip tüketicilere dönüşmektedir (Borg, 1999; UNWTO, 2015). Turistlerin çevre bilincinin ve duyarlılığının artmasına bağlı olarak, istek ve beklentileri karşılamak isteyen konaklama işletmeleri aynı zamanda sürdürülebilir rekabet avantajı sağlamak, maliyetlerini azaltarak karlarını arttırmak ve devlet tarafından sağlanan teşvik ve indirimlerden faydalanmak istemektedir. Çevrenin ve doğal kaynakların turizm faaliyetlerini gerçekleştirebilmek için önemli olduğunu düşünen turistler de çevreye duyarlı konaklama işletmelerini tercih etmeye ve ekosisteme zarar vermeden tatillerini gerçekleştirmeye özen göstermektedir (Ayaş, 2007). Çevreye duyarlı olan bu turistler, aynı zamanda destinasyonlarda ve turistik işletmelerde bulunan çevreye duyarlı üretim ve hizmet faaliyetlerini çeşitli bilgi kaynakları ile takip etmektedir (Gössling, 1999).

Çevre ile ilgili artan hassasiyete paralel olarak alanyazında da konuya olan ilgi artmıştır. Virginia Polytechnic Üniversitesi tarafından Amerika'da beş yüze yakın otel misafiri ile gerçekleştirilen araştırmada, katılımcıların büyük çoğunluğunun yeşil otellerde konaklamayı tercih ettikleri ve otellerin enerji ve su tasarrufu ile geri dönüşüm yapmaları gerektiğini düşündükleri ortaya çıkmıştır. Katılımcıların çevre dostu uygulamalar için daha fazla para ödemeye gönüllü olmadıkları da araştırmanın bulguları arasındadır (Watkins, 1994). Hindistan'da yürütülen bir diğer araştırmada, tüketicilerin otellerin yeşil uygulamalarını somut biçimde görmek istedikleri ve çevreyle ilgili ortaklık ya da sertifikasyon programlarının konaklama kararını etkilediği ifade edilmiştir. Araştırmada ayrıca tüketicilerin çoğunluğunun yeşil uygulamalar için fazla para ödemeye gönüllü olmadıkları; ancak aynı hizmeti sunması halinde çevre dostu olan otelin olmayanın önüne geçeceği sonucuna varılmıştır (Manaktola ve Jauhari, 2007). Otel odalarındaki çevre dostu uygulamalar hakkında gerçekleştirilen bir araştırmada, katılımcıların oda tercihindeki en etkili unsurun yeşil otel sertifikası olduğu belirlenmiştir. Çevre dostu odalarda konaklamak için daha fazla para ödemeye gönüllü olan katılımcı sayısının oldukça düşük olduğu da elde edilen bulgular arasındadır (Millar ve Baloglu, 2011). Öte yandan Han ve diğerleri (2009) günlük yaşamlarında çevreye duyarlı olan ve yeşil otellere yönelik olumlu imaja sahip turistlerin yeşil otellerde kalma, bu otelleri tavsiye etme ve bu otellere daha fazla ödeme yapmaya istekli olduklarını belirtmiştir. Çevre bilinci ve çevre dostu otel algısının davranışsal 
niyetler üzerindeki etkisini belirlemek amacıyla yapılan bir başka araştırmada da konaklama tesislerinin çevreye duyarlı olup olmamasının turistlerin rezervasyon kararlarını etkilediği sonucuna varılmıştır (Yıldız ve Kılıç, 2016).

Konaklama işletmelerinin çevreye duyarlılık düzeyleri ve çevreye duyarlı örnek uygulamaları da son yıllarda araştırmacıların ağırık verdiği konular arasındadır (Eren ve Yılmaz, 2008; Seyhan ve Yılmaz, 2010; Atay ve diğ., 2013; Aykan ve Sevim, 2013; Akdağ ve diğ., 2014; Yıldırım-Saçılık ve Çevik, 2014; Giritlioğlu ve Güzel, 2015). Atay ve Dilek (2013) yeşil pazarlama konusunda öncü bir konaklama işletmesi ile ilgili yürüttükleri araştırmalarında, otelin çevreyle ilgili uygulamalarının müşteri ve çalışanlar tarafından olumlu karşılandığını, pazarlama açısından önemli bir etki yarattığını ve rekabet avantajı sağladığını, işletmenin mevcut kurumsal imajına güç kattığını ve tüketicilerin algısındaki tercih edilebilirliği arttırdığını belirtilmiştir. Yılmaz ve Yumuk (2013), yeşil yıldızın işletmelerin imajını destekleyen ve yeşil uygulamaları belirginleştiren bir araç olarak görüldüğünü ortaya koymuştur. Sezen-Doğancili ve Akbulut (2015) yeşil yıldız belgeli otellerin web sitelerinde yeşil pazarlamayı kullanımlarına ilişkin yaptıkları araştırmada, işletmelerin çevre ile ilgili konuları daha çok web sitelerinin giriş sayfalarında ele aldıklarını ve en çok ödül ve sertifikalar sekmesinin kullanıldığını göstermiştir. Araştırmada yeşil yönetim sertifikasına sahip olduğu halde konu ile ilgili bilgilendirme yapmayan işletme sayısının oldukça fazla olduğu ve işletme tanıtımında yeşil yönetim uygulamalarına ait bilgilerin yeterince kullanılmadığı ifade edilmiştir.

\section{2. Çevre Yönetim Sistemleri}

Çevre yönetim sistemleri otuz yılı aşkın bir süredir turizm endüstrisinde sürdürülebilir uygulamaları benimseyerek turizm tedarikçilerine yardımcı olmaktadır (Mihalic, 2000; Sasidharan ve diğ., 2002). Turizm endüstrisinde uluslararası düzeyde faaliyet gösteren konaklama işletmeleri çevreyi korumak, enerji maliyetlerini düşürmek, değişen turist profiline cevap verebilmek ve pazarda rekabet avantajı elde edebilmek için eko-etiket de denilen birçok çevre yönetim sistemi sertifikasını kullanmaktadır. Dünya üzerinde turizm işletmeleri tarafından kullanılan yüzün üzerinde sertifika mevcuttur (Esparon ve diğ., 2014; Font, 2002; Font ve Buckley, 2001; Gössling ve Buckley, 2016). Biohotels, Energy Star, Enviro-Mark, European Ecotourism Labelling Standard, Florida Green Lodging Program, Green Star Hotel, Green Flag Award, International Eco Certification Program, National Tourism Accreditation Framework, Responsible Tourism System, Sustainable Tourism Eco-Certification Program konaklama işletmelerinin aldığı bazı çevre yönetim sistemi sertifikalarıdır (Gössling ve Buckley, 2016).

Türkiye'deki konaklama işletmeleri uluslararası düzeyde LEED (Leadership in Energy \& Enviromental Design), ISO 14000 ve ISO 14001, GreenGlobe, GTBS (Green Tourism Business Scheme), Travelife (Sustainability in Tourism), Green Key, TUI Umwelt Champion\&Eco Resort gibi çevre yönetim sistemi sertifikalarını kullanmaktadır. LEED (2016), Amerikan Yeşil Binalar Konseyi tarafından verilen ve dünyada en yaygın kullanılan yeşil bina derecelendirme etiketlerinden biridir. Bu programın amaçları, insan ve çevre sağlığına etki etmeyen malzemeler kullanmak, kapalı ortamların çevre kalitesini yükseltmek ve yenilenebilir enerji kaynaklarını kullanarak binaların enerji intiyacını karşılamaktır. Su kaynakları ve ekosistemler üzerindeki etkileri en aza indirgemek, su ve enerji verimliliğini arttırmak, sürdürülebilir yapı malzemeleri kullanımını ve hava kalitesi için atıkların azaltılmasını sağlamak için de bu sistem kullanılmaktadır (Goodwin, 2014). 
ISO 14000 ve ISO 14001 Uluslararası Standartlar Örgütü tarafından uygulanan bir çevre yönetim sistemidir. Bu sistem, doğal kaynak kullanımının azaltılması, toprağa, suya, havaya verilen zararların en aza indirilmesini amaçlayan ve risk analizleri tabanında kurulan bir yönetim modelidir (Standart Kalite, 2016). ISO, turizm işletmelerinde çevresel yükümlülükleri belirlemek amacıyla bir çerçeve sunan, hava, su ve toprak kalitesini korumak için üç yüzden fazla standarda ve prosedüre sahiptir (Toht, 2002). GreenGlobe (2016), dünya çapında seksenin üzerinde ülkede sertifikası verilen, işletmeler, çalışanlar ve yerel halka önemli çıktılar sunan bir çevre yönetim sistemidir. 1998 yılında uygulanmaya başlanan bu çevre yönetimi sistemi, standartlarını yerine getiren işletmeleri sisteme kaydederek GreenGlobe logosunu kullanmalarına izin vermektedir (Font, 2002).

GTBS, 1997 yılından beri faaliyet gösteren dünya çapında iki binden fazla üyesi bulunan doğal kaynakları koruma, kirliliği en aza indirme, yerel kültürlere saygı duyma gibi amaçları olan bir sürdürülebilir turizm sertifikasyon programıdır (Green Tourism, 2016). Çevre mevzuatına uyum, personel eğitimi, enerji ve su verimliliği, çevreye duyarlı ürün ve hizmet kullanımı, atıkların ayrıştırılması, yerel ürünlerin kullanılması, toplu taşımanın teşvik edilmesi, yaban hayatının korunması ve geri dönüşüm gibi kriterlerin sağlanmasıyla GTBS sertifikasına sahip olunmaktadır (Jarvis ve diğ., 2010). Travelife (2016) dünya çapında faaliyet gösteren konaklama işletmelerinin çevre, sosyal ve ekonomik etkilerini en aza indirgemeyi amaçlayan uluslararası sürdürülebilir sertifikasyon programlarından biridir. Bu çevre yönetim sisteminin amacı, sürdürülebilirlik faaliyetlerini başarılı bir şekilde gerçekleştiren konaklama işletmelerine eko-etiketi vererek onları teşvik etmektir (Camilleri, 2014).

Green Key (2016), çevre dostu sürdürülebilir teknolojileri uygulamayı ve kaynak kullanımını en aza indirgemeyi amaçlayan bir çevre ödülü programıdır. Enerji yönetimi, düşük enerjili ampullerin maksimum kullanımı, atıkların ayrıştırılması ve kahvaltıda en az iki organik ürünün olması gibi bir dizi zorunlu koşulu sağlaması durumunda konaklama işletmelerine verilen çevre yönetim sistemidir (Bramwell ve Alletorp, 2001). TUI Umwelt Champion ise TUI (2016) tarafından binlerce konaklama işletmesi arasından bağımsız değerlendirmeler sonucunda çevre dostu olduğu kanıtlanan tesislere verilen çevre şampiyonu ödülüdür.

Türkiye'de en çok verilen çevre yönetim sistemi etiketleri arasında Mavi Bayrak, Yeşil Anahtar ve Yeşil Yıldız yer almaktadır. Mavi Bayrak, Türkiye Çevre Eğitim Vakfı (TÜRÇEV) tarafından yüzme amacıyla kullanılan suyun niteliğini koruyan, plajın düzenini ve emniyetini sağlayan, çevre yönetimi bulanan plaj ve marinalara bir yıl için verilen ödüldür (KTB(a), 2016). 2016 yılı itibariyle sahip olduğu 444 adet Mavi Bayraklı plajı ile Türkiye, Avrupa'nın en fazla mavi bayraklı plaja sahip ikinci ülkesi olmuştur (TÜRÇEV, 2016). Yeşil Anahtar da TÜRÇEV tarafından Uluslararası Çevre Eğitim Vakfı (FEE) ile uyumlu olarak çevrenin korunması, iklim değişikliğinin önlenmesi ve sürdürülebilir turizme destek vermek amacıyla verilen bir çevre yönetimi sertifikasyon programıdır. 2016 yılı itibariyle Türkiye'de Yeşil Anahtar ödülüne sahip 74 tesis bulunmaktadır (TÜRÇEV, 2016). Konaklama işletmeleri bunlar dışında Beyaz Yıldız ve Yeşillenen Oteller gibi etiketlere de başvurabilmektedir. Beyaz Yıldız, Türkiye Otelciler Federasyonu (TÜROFED) tarafından 2008 yılında verilmeye başlanan su, elektrik, kimyasal ve katı atık miktarını azaltmayı, çevreye oluşabilecek zararları en aza indirgemeyi amaçlayan bir diğer ödül sistemidir (Turizm Dünyası, 2008). Yeşillenen Oteller ise 2009 yılında TUROB tarafından verilmeye başlanan Bureau Veritas ve Sürdürülebilirlik Akademisi iş birliği ile devam eden bir sertifikasyon projesi olup, yeşil konaklama tesislerinin sayısını artırmayı amaçlamaktadır. 2016 yılında Türkiye'deki Yeşillenen Oteller sertifikalı tesis sayısı 53'e ulaşmıştır (Greening Hotels, 2016). 
Kültür ve Turizm Bakanlığı tarafından verilen ve bu araştırmanın temelini oluşturan Yeşil Yıldız, sürdürülebilirlik kapsamında çevrenin korunması, çevre bilincinin geliştirilmesi, turistik işletmelerin çevreye olan olumlu katkılarının teşvik edilmesi ve özendirilmesini amaçlayan konaklama tesislerine verilen bir belgedir (KTB(b), 2016). Kültür ve Turizm Bakanlığı tarafından 1993 yılında "Turizmde Çevreye Duyarlılık Kampanyası" başlatılmış ve talep eden ve aranılan nitelikleri taşıyan konaklama işletmelerine "Çevre Dostu Kuruluş Belgesi" (Çam Simgesi) verilmeye başlanmıştır. Bu belge için aranan kriterler yaşanan gelişmelere paralel olarak geliştirilmiş ve 2008 yılında "Çevreye Duyarlı Konaklama Tesisi Belgesi" olarak değiştirilmiştir. Bu belge ile turistik konaklama işletmelerindeki çevreye duyarlı yapılaşmanın, işletmecilik özelliklerinin ve diğer yönleriyle çevreye olan olumlu katkıların teşvik edilmesi ve çevre bilincinin geliştirilmesi amaçlanmıştır (KTB(b), 2016).

Yeşil yıldız belgesi, çevreye duyarlıık konusunda çalışma yapan turistik işletmelerin talebi üzerine ve formun uygulama esaslarında belirlenen temel kriterlere sahip olan konaklama tesislerine uygulanmaktadır. Konaklama işletmelerinin kapasiteleri ile çevreye olan etkileri dikkate alınarak, işletmelerin tür ve sınıflarına göre asgari puanlar belirlenmiştir. Yıldızlı konaklama tesislerinin bu formda belirlenen asgari puanları aşması durumunda plaketlerinde sınıfını gösteren yıldızlar yeşil renkli düzenlenmekte ve ayrıca plaket üzerinde "Çevreye Duyarlı Tesis" ibaresi yer almaktadır.

\section{Tablo 1: Yeşil Yıldız Belgeli Konaklama İşletmelerinin Yıllara Göre Sayıları}

\begin{tabular}{|l|l|}
\hline YII & Otel Sayıs I \\
\hline 2008 & 0 \\
\hline 2009 & 2 \\
\hline 2010 & 10 \\
\hline 2011 & 22 \\
\hline 2012 & 31 \\
\hline 2013 & 52 \\
\hline 2014 & 188 \\
\hline 2015 & 223 \\
\hline 2016 & 309 \\
\hline
\end{tabular}

Kaynak: TUYUP, 2016; KTB(b), 2016

Çevre koruma yasalarının giderek artan baskısı, çevre tahribatının turizme olumsuz etkileri ve çevreye duyarlı turist sayısı ile konuya karşı artan hassasiyet işletmeleri çevreye karşı sorumlu hale getirmekte ve önlem almaya zorlamaktadır. Bu gelişmelerin bir sonucu olarak, çevreye duyarlı uygulamaları ile yeşil yıldız belgesi alan konaklama işletmelerinin sayısı her geçen gün hızla artmaktadır (Tablo 1).

\section{Araştırmanın Yöntemi}

Yeşil yıldız belgeli konaklama işletmelerinin çevre duyarlılığını incelemek ve bu uygulamalardan hangilerine daha fazla vurgu yaptıklarını belirlemek amacıyla yürütülen bu araştırmanın iki temel sorusu vardır:

a) Yeşil yıldız belgeli konaklama işletmelerinin web sitelerinde yeşil yıldız ve diğer çevre uygulamaları hakkında bilgi veriliyor mu?

\footnotetext{
1 “Turizm İşletmesi Belgeli Konaklama Tesislerine Verilmesine Dair 2008/3 no'lu Tebliğ" ekinde, 22.09.2008 tarih ve 27005 sayılı Resmi Gazetede yayımlanarak yürürlüğe girmiştir.
} 
b) Yeşil yıldız belgeli konaklama işletmelerinin web sitelerinde yer alan çevreye duyarlılık bilgilerinde hangi uygulamalara daha fazla yer verilmektedir?

Yeşil yıldız belgeli konaklama işletmelerinin çevreye duyarlı uygulamalarını belirlemek için web sitelerinin incelendiği bu araştırmada Kültür ve Turizm Bakanlığı'nın 31.05.2016 tarihli "Çevreye Duyarlı Konaklama Tesisleri" listesi kullanılmıştır. Araştırmanın evrenini belirtilen tarihte Türkiye'de yer alan 309 yeşil yıldız belgeli konaklama işletmesi oluşturmaktadır. Bu işletmelerin tamamı tam sayım yöntemine göre analiz edilmiştir. Araştırmada veri toplama yöntemi olarak doküman incelemesi yapılmıştır. Doküman incelemesi tek başına bir veri toplama tekniği olarak ele alınabileceği gibi araştırmanın temel sorunsalı çerçevesinde de araştırmaya dahil edilebilir (Yıldırım ve Şimşek, 2013). Araştırma kapsamında, ilk olarak yeşil yıldız belgeli konaklama işletmelerinin çevre ile ilgili uygulamalarına web sitelerinde yer verip vermedikleri incelenmiş, ardından çevre uygulamaları hakkında bilgi veren işletmelerin web siteleri kantitatif ve kalitatif içerik analizine tabi tutulmuştur. İçerik analizi, bir metin içindeki mesajların ve anlamların anahtar kelime olarak yer aldığı verilerin kodlanmasını ve kategorilerin oluşturulmasını içermektedir (Merriam, 2013).

Araştırmada Kültür ve Turizm Bakanlığı'nın yeşil yıldız kriterleri temel alınmıştır. $\mathrm{Bu}$ aşamada üç araştırmacı bu kriterler üzerinden kategorileri ve alt kategorileri oluşturmuş ve daha sonra bunlar içinden ortak olanları seçerek konaklama işletmelerinin web sitelerini incelemiştir. Araştırmanın geçerlik ve güvenirliğinin sağlanması için Guba (1981)'nın güvenirlik, aktarılabilirlik, tutarlııık ve doğrulanabilirlik temel ölçütleri çerçevesinde geliştirmiş olduğu "güvenirlik modeli" temel alınmıştır. Bu kapsamda, belirlenen kategoriler ve alt kategoriler alanında uzman iki akademisyen görüşüne sunulmuş ve son halini almıştır. Kodlama süreci, metin ve görsellerden elde edilen verileri küçük bilgi kategorileri içine toplamayı, çalışmalarda kullanılan farklı veri tabanlarından gelen kodlar için kanıt aramayı ve sonra bu kodlara etiket vermeyi içermektedir (Creswell, 2016).

Araştırmacılar, 2014-2016 yılları arasında farklı zamanlarda güncellenen listeleri dikkate alarak konaklama işletmelerine ait web sitelerini belirlenen kategoriler ve alt kategoriler doğrultusunda tek tek analiz etmiş, daha sonra bir araya gelerek üzerinde fikir birliğine varana kadar analizlere devam etmiştir. Son olarak, betimsel analiz yöntemiyle konaklama işletmelerinin örnek uygulamalarından alıntılar yapılarak bulgular yorumlanmıştır. Analizler sonucunda, yedi kategori ve 12 alt kategori elde edilmiştir. Bu kategoriler, konaklama işletmelerinin genel yönetim kategorisi altında çevre politikası ve etkinlikler, eğitim kategorisi altında personel eğitimi ve misafir eğitimi, çevre uyumu kategorisi altında ekolojik çevre ve ekolojik mimari, enerji ve su kategorisi altında enerji tasarrufu, su tasarrufu ve yenilenebilir enerji kaynağı kullanımı, atıklar ve kimyasallar kategorisi altında atıkların değerlendirilmesi ve kimyasalların kullanılmaması, yiyecek-içecek ve çevre ile ilgili diğer konularda yaptığı uygulamalar olarak belirlenmiştir.

Araştırma kapsamında yeşil yıldız belgeli iki konaklama işletmesinin web sitesine ulaşılamamıştır. Bunun sebebi Kültür ve Turizm Bakanlığı'nın çevreye duyarlı konaklama işletmeleri listesinde yer alan bazı tesis isimlerinin farklılık göstermesidir. Öte yandan konaklama işletmeleri web sitelerinde belirtmediği birçok çevre uygulamasını gerçekleştirebilmektedir ancak bu çalışma yalnızca web sitelerinde belirtilen çevreye duyarlılık bilgileri ile sınırlıdır. 


\section{Bulgular}

Araştırma kapsamında ele alınan yeşil yıldız belgeli konaklama işletmelerine ait profil bilgisi Tablo 2'de yer almaktadır.

Tablo 2: Yeşil Yıldız Belgeli Konaklama İşletmelerinin Profil Bilgisi

\begin{tabular}{|c|c|c|c|c|c|}
\hline Tesis Sınıfı & Sayı & Yüzde & Yer & Sayı & Yüzde \\
\hline 5 Yıldızlı & 220 & 71 & Antalya & 162 & 52 \\
\hline 4 Yıldızlı & 53 & 17 & İstanbul & 45 & 15 \\
\hline 3 Yıldızlı & 8 & 3 & Muğla & 26 & 8 \\
\hline Diğer & 28 & 9 & İzmir & 17 & 6 \\
\hline Toplam & 309 & 100 & Ankara & 10 & 3 \\
\hline İhtiyaç Türü & Sayı & Yüzde & Diğer iller & 49 & 16 \\
\hline Resort & 205 & 66 & Toplam & 309 & 100 \\
\hline Şehir & 104 & 34 & Çevreye Duyarlılık Bilgisi & Sayı & Yüzde \\
\hline Toplam & 309 & 100 & Yok & 119 & 39 \\
\hline Mülkiyet Türü & Sayı & Yüzde & Var & 106 & 34 \\
\hline Zincir & 205 & 66 & Sadece ödül\&sertifika bilgisi & 82 & 26 \\
\hline Bağımsız & 104 & 34 & Web sitesine ulaşıllamayan & 2 & 1 \\
\hline Toplam & 309 & 100 & Toplam & 309 & 100 \\
\hline
\end{tabular}

* Tabloda verilen yüzdelik rakamlar yuvarlanarak hesaplanmıştır.

Araştırma dahilindeki işletmelerin büyük çoğunluğu beş yıldızlı, resort ve zincir otellerden oluşmaktadır. Bu işletmelerin yarısından fazlası Antalya'da yer almaktadır. 119 işletmenin web sitelerinde çevreye duyarlı uygulamaları ile ilgili herhangi bir bilgi bulunmazken, 82 konaklama işletmesi de sadece çevre ile ilgili kazanılan ödül ve sertifikalarının bilgisini ya da logosunu paylaşmaktadır. Bu sebeple, içerik analizi çevreye duyarlı uygulamaları hakkında bilgi veren 106 konaklama işletmesinin web siteleri üzerinden gerçekleştirilmiştir.

İşletmelerin web sitelerinde belirtilen ödül ve sertifikaların dağılımı Tablo 3'te verilmektedir. Buna göre, araştırma kapsamındaki işletmelerin hepsi yeşil yıldız belgesine sahip olmasına rağmen yalnızca 91 işletme web sitelerinde bu ödül ile ilgili bilgi vermektedir. Kültür ve Turizm Bakanlığı'nın yeşil yıldız kriterlerine göre çevre ile ilgili sahip olunan diğer ödül ve sertifikalar tesislere ek puan sağlamaktadır, bu sebeple diğer ödül ve sertifikaların dağılımı da çalışmada analiz edilmiştir.

Tablo 3: Yeşil Yıldız Belgeli Konaklama İşletmelerinin Sahip Olduğu Ödül ve Sertifikalar

\begin{tabular}{|l|l|l|}
\hline Ödül ve Sertifikalar & Sayı & Yüzde \\
\hline Yeşil Yıldız & 91 & 29 \\
\hline Mavi Bayrak & 85 & 27 \\
\hline Travelife & 57 & 18 \\
\hline ISO14001 & 48 & 16 \\
\hline Yeşil Anahtar & 23 & 7 \\
\hline TUI & 23 & 7 \\
\hline Beyaz Yıldız & 18 & 6 \\
\hline Yeşillenen Oteller & 10 & 3 \\
\hline Diğer & 14 & 5 \\
\hline \multicolumn{2}{|c|}{ Toplam Konaklama Işletmesi Sayısı:309 } \\
\hline
\end{tabular}


Çevre ile ilgili uygulamalarına web sitelerinde yer veren 106 konaklama işletmesinin çevreye duyarlılık bilgileri genel yönetim, eğitim, çevre uyumu, enerji ve su, atıklar ve kimyasallar, yiyecek-içecek ve diğer olmak üzere yedi kategori ve bunlara bağlı alt kategoriler altında incelenmiştir. Yapılan içerik analizi sonuçları Tablo 4 'te yer almaktadır. Konaklama işletmelerinin web sitelerinde yer alan çevreye duyarlı uygulamaları incelendiğinde, en fazla çevre politikası ve atıkların değerlendirilmesine, en az da ekolojik mimari ile ilgili bilgiye yer verildiği görülmektedir.

\section{Tablo 4: Yeşil Yıldız Belgeli Konaklama İşletmelerinin Web Sitelerindeki Çevreye Duyarlılık Bilgisi}

\begin{tabular}{|l|l|l|l|l|l|}
\hline Genel Yönetim & Sayı & Yüzde & Enerji ve Su & Sayı & Yüzde \\
\hline Çevre Politikası & 99 & 94 & Enerji Tasarrufu & 69 & 66 \\
\hline Etkinlikler & 30 & 29 & Su Tasarrufu & 59 & 56 \\
\hline Eğitim & $\begin{array}{l}\text { Yenilenebilir Enerji Kaynağı } \\
\text { Kullanımı }\end{array}$ & 37 & 35 \\
\hline Personel Eğitimi & 80 & 76 & Atıklar ve Kimyasallar \\
\hline Misafir Eğitimi & 72 & 69 & Atıkların Değerlendirilmesi & 93 & 89 \\
\hline Çevre Uyumu & $\begin{array}{l}\text { Kimyasalların } \\
\text { Kullanılmaması }\end{array}$ & 49 & 47 \\
\hline Ekolojik Çevre & 46 & 44 & Yiyecek-Içecek & 22 & 21 \\
\hline Ekolojik Mimari & 13 & 12 & Diğer & 22 & 21 \\
\hline
\end{tabular}

Araştırma kapsamındaki işletmelerin tamamına yakını genel yönetim kapsamında çevre politikaları hakkında bilgi vermektedir. Çevre politikaları; su, enerji, elektrik tüketimi konusunda tasarruf yapma, kimyasal ve atık miktarını izleme ve veri toplama gibi konularda eylem planları ve çevreyi koruma hedefleri ile ilgili bilgiler içermektedir. Çevre politikalarından örnekler aşağıda verilmektedir.

"Ailenizle iyi vakit geçirebileceğiniz ve güzel anılar biriktirebileceğiniz bu eşsiz tesis, size hizmet verirken doğayı korumayı da göz ardı etmemektedir. Çevreyi korumak, en az kendimize olduğu kadar diğer canlılara da saygı göstermek ve yaşam haklarını savunmak adına benimsediğimiz çevre politikasını, güncel yasa ve uygulamalar çerçevesinde ve en önemlisi siz misafirlerimizin desteğiyle hayata geçirebilmek yegane amacımızdır." (Otel 8)

"Doğal kaynakların tasarruflu kullanımının ve bu kaynakların etkin bir şekilde yönetilmesinin, turizmin sürdürülebilirliğinin sağlanması açısından çok önemli olduğuna inanmaktayız. Çevre konusunda gerçekleştirdiğimiz uygulamalarla Akdeniz bölgesinde otelcilik sektöründe örnek bir işletme olmayı hedeflemekteyiz." (Otel 14)

"Otelimiz bünyesinde kurduğumuz çevre yönetim sistemi ile siz misafirlerimizin konforundan taviz vermeden, su, elektrik, enerji, kimyasal, katı atık miktarlarının kontrol altına alınması, çevreye ve doğal kaynaklara yönelik oluşabilecek zararın en aza indirilmesi hedeflenmektedir." (Otel 83)

Çevre ile ilgili yapılan etkinlikler hasat şenliği, ağaç dikimi, çocuklar ve yerel halk için yapılan etkinlikleri içermektedir. Bu kapsamda Otel 4, karbon ayak izini azaltmak için Atatürk Orman Çiftliği'nde ağaç dikimi gerçekleştirmekte ve diğer bazı işletmeler de çevrelerinde bulunan alanlarda ağaç dikme faaliyetleri düzenlemektedir. Otel 67 , her yıl öğrencilerle beraber gerçekleştirdiği ağaç dikimi faaliyetlerini bu okulların doğal 
kaynakların kullanılması ile ilgili çevre bilinci panolarında sergilemektedir. Otel 61, beş ve üzeri konaklama yapan misafirleri adına otel bahçesinde fide dikmektedir. Otel 14, sosyal sorumluluk kapsamında tüm personelin katılımı ile halk plajları ve ormanlık alanlarda sezon sonu ve sezon başında mıntıka temizliği yapmaktadır. Otel 35 de benzer biçimde çevre temizliği etkinlikleri kapsamında misafirlerin ve personelin katılımı ile göl çevresi temizliği gerçekleştirmektedir. Bunlar dışında bazı konaklama işletmeleri bahçelerinde birçok farklı meyve ağacı bulundurmakta ve farklı mevsimlerdeki hasat zamanlarında misafirleri ile meyve toplama etkinlikleri düzenlemektedir.

Konaklama işletmeleri personel ve misafirlerine çevre konusunda eğitim vererek çevre bilincini arttırdığını ve konu ile ilgili bilgilendirmeler yaptığını web sitelerinde belirtmektedir. Bu kapsamda Otel 78, bölüm müdürleri aracılığıyla personelinin çevreye olan duyarlılığının artması için sürdürülebilirlik eğitimleri gerçekleştirmektedir. Otel 40, kimyasalların kullanımı ve tehlikeli kimyasalların dökülüp saçılması durumunda alınacak tedbirler konusunda çalışanlarını bilgilendirmektedir. Otel 35, aktiviteler sırasında çocuklara çevre konusunda eğitimler vermekte ve aynı zamanda tüm personeline de çevre eylem planı, tasarruflu enerji, su ve kimyasal kullanımı ve atık bertaraf konularında periyodik eğitimler vermektedir. Otel 49 ve 104 de çocuklar için doğayı tanıtıcı ve çevre konusunda eğitici faaliyetler ve animasyon gösterileri düzenlemektedir. Otel 67 ise çevreye gösterdiği önemi ve uyumu web sitesinde yer alan biyo-çeşitlilik videosu ile anlatmaktadır.

Çevre uyumu; çevreyi güzelleştirici düzenleme ve etkinlikler, peyzaj düzenleme ve ağaçlandırma, yapıların görsel olarak doğa ile uyumlu olması, çevrede bulunan vahşi veya evcil hayvanları koruma, sağlık, bakım ve besleme ile ilgili çalışmalar yapma ve envanteri bulunan endemik bitkileri koruma ve ekosistemin bozulmaması için özen gösterme gibi uygulamaları içermektedir. Bu kapsamda ekolojik mimari de tesisin mimari tasarımının çevreye duyarlı olması, mimari yapı, konum ve yapı elemanlarının doğal havalandırmayı sağlaması, ısı yalıtımının iklim şartlarına uygun, minimum enerji ile yeterli soğutma ve ısıtma sağlaması, dış cephede kullanılan camların ısı geçişlerini kontrol etmesi, dış cephede güneşi kontrol eden yapı elemanlarının bulunması gibi özellikleri kapsamaktadır.

Araştırmadaki konaklama işletmeleri daha çok ekolojik çevre ile ilgili uygulamaları hakkında bilgi vermektedir. Nesli tükenme tehlikesiyle karşı karşıya olan hayvanları ve endemik bitkileri koruma, diğer bazı hayvan türlerinin bakımı ve kedi evi projeleri buna örnek olarak verilebilir. Denize kıyısı olan konaklama işletmelerinin birçoğu çevre politikaları doğrultusunda plajlarına gelen Caretta Caretta kaplumbağalarını, diğer bazı hayvan türlerini ve bahçelerinde yer alan bitki türlerini koruma altına alarak doğal hayatın korunmasına yardımcı olmaktadır. Bir konaklama işletmesi bu durumu aşağıdaki gibi ifade etmektedir.

"Antalya kıyı şeridi Caretta Caretta yuvalama alanlarından birisidir. 1 Mayıs - 1 Ekim tarihleri arasında üreme mevsimi olan deniz kaplumbağalarını korumak ve onlarla birlikte yaşamak için sahilde gerekli düzenlemeler yapılmakta, misafirlerimiz broşürler ve uyarı levhaları ile bilgilendirilmektedir." (Otel 14)

Otel 70, nesli tehlike altındaki hayvan türlerinden evlat edinerek doğayı koruma çalışmalarına destek olmakta ve misafirlerini de bu konuda teşvik etmektedir. Bunun dışında bazı konaklama işletmeleri sokak kedileri için kedi evleri yaparak, kedileri düzenli olarak veteriner kontrolünden geçirmekte ve aşılarını yaptırmaktadır. Otel 49, hayvanlar için kendi doğal ortamlarının yaratılı̆̆ı bir hayvanat bahçesi ile çeşitli 
hayvan türlerini barındırmakta ve korumaktadır. Otel 35 de benzer biçimde çocuk misafirlerin hayvanları tanıması ve onlarla iletişime geçmesi için kurgulanmış bir mini hayvanat bahçesine sahiptir. Otel 67 ve 104, çeşitli kuş türlerini korumak için kuş evleri inşa etmiştir. Otel 65 ise sahilinde doğal olarak yetişen ve mevcut olduğu tespit edilen endemik bitki türlerini uyarı levhası ile işaretlemekte ve misafirlerine yönlendirmeler yapmaktadır.

Ekolojik mimari uyumunda ise çevre dostu inşaat malzemeleri ile doğal içerikli malzemeler ve çevre korumaya uygun teknolojik donanımların kullanılması yer almaktadır. Konaklama işletmelerinin ekolojik mimari ile ilgili uygulamalarına Otel 64 ve 69 'un çevre ile en uyumlu teknolojiye sahip ekipmanları seçerek emisyonlarını minimuma indirme hedefleri örnek gösterilebilir. Otel 86 da sürdürülebilir enerji kullanımının esas olduğu düşük karbon ayak izine sahip hafif çelik sistemi ile inşa edilmiştir. İşletme aynı zamanda her ölçeğinde geri dönüşümlü ve doğal içerikli malzemeler kullanmakta ve sürdürülebilir peyzaj anlayışını benimsemektedir.

Konaklama işletmelerinin çevreye duyarlı uygulamaları arasında enerji ve su tasarrufu ile güneş, rüzgâr, jeotermal, hidro, dalga enerjisi ve biyo-kütle gibi yenilenebilir enerji kaynaklarının kullanımı yer almaktadır. Araştırmada işletmelerin daha çok enerji ve su tasarrufuna önem verdiği, yenilebilir enerji kaynaklarını ise daha az kullandığı görülmektedir. Buna göre, konaklama işletmelerinin çoğu su, elektrik ve enerji miktarlarını kontrol altına almayı, çevreye ve doğal kaynaklara yönelik oluşabilecek zararları en aza indirmeyi hedeflemektedir. Örneğin, Otel 73 elektrik, su ve doğal gazdan elde ettiği yıllık tasarruf değerlerini her yıl web sitesinde yayınlayarak misafirlerinin dikkatini çekmeye çalışmaktadır. Bu doğrultuda, çevre politikaları yürürlüğe girdiği tarihten itibaren 816 ailenin yıllık elektrik tüketimi, 105 ailenin yıllık doğalgaz tüketimi ve 339 ailenin yıllık su tüketimi kadar tasarruf sağladığını duyurmuştur. Otel 10, su tasarrufu amacı ile damlama sulama yöntemini kullanmaktadır. Otel 28, 29, 30 ve 67 yenilenebilir enerji kaynaklarını kullanarak tesis genelinde kullanılan sıcak suyun yarısından fazlasını güneş enerjisinden elde etmektedir. Otel 84, ısıtma ve sıcak su kullanımında yenilenebilir ve çevre dostu olması sebebiyle termal suyu tercih etmektedir. Otel 2, mutfaklarında LPG ve sıcak su için jeotermal enerji; Otel 100 ise Isıtma sisteminde biyo-kütle enerjisi ve elektrik tüketiminde de rüzgâr enerjisini kullanmaktadır.

Çevreye duyarlı konaklama tesisi kriterlerinde yer alan deterjanlar, dezenfektanlar ve tehlikeli kimyasal maddeler ölçütünde, çevreye duyarlı deterjan ve dezenfektan kullanma, uygun alanlarda kimyasal madde kullanılmaksızın temizlik yapma, haşere ile mücadelede insan sağlığına ve çevreye zarar vermeyen ilaçlar kullanma veya doğal tedbirler alma gibi maddeler yer almaktadır. Atıklar konusunda ise artan sağlıklı günlük yiyecekleri hayır kurumlarına verme, ilgili kurumlarla iş birliği, misafirlerin atıkları ayırabilmeleri için yeterli kutu bidon sağlama, zararlı atıkları diğerlerinden ayırma, kullanılabilir atıkları çeşitlerine ayırma, organik atıkları kompost ve biyogaz gibi yöntemlerle değerlendirme gibi uygulamalar yapılması gerekmektedir.

Konaklama işletmelerinin atıklar ve kimyasallar ile ilgili durumları incelendiğinde, tamamına yakınının atıkları değerlendirdiği, kimyasal kullanımını azaltma konusunda ise daha az uygulama yaptıkları görülmektedir. Otel 77 , kâğıt geri dönüşümü ile ağaçların kesilmesini önlemekte, metal geri dönüşümü ile ham madde tasarrufu sağlamakta, cam geri dönüşümü ile karbondioksit emisyonunu engellemekte ve plastik ambalaj atıkların geri dönüşümü ile enerji tasarrufu sağlamaktadır. Otel 73, atıkları mümkün olduğunca kaynağında azaltmakta veya kullanılmış ambalajlar ile diğer değerlendirilebilir atıkları genel çöplerden ayrıştırarak geri kazanmaktadır. Bu 
kapsamda kağıt ve kartonların geri dönüşümü ile 605 adet ağacın kesilmesi önlenerek 1.282 ton karbondioksit gazının atmosfere salınmasının önüne geçilmiş, plastik atıkların geri dönüşümü sayesinde 268.496 kWh enerji tasarrufu ve cam atıkların geri dönüştürülmesi ile 147 litre petrol tasarrufu sağlanmış, pillerin geri dönüştürülmesi ile $411.111 \mathrm{~m}^{2}$ toprağın ve 51 milyar litre suyun cıva nedeniyle kirlenmesi, atık yağların toplanması ve yeniden değerlendirilmesi sayesinde 10.5 milyar $\mathrm{m}^{3}$ içme suyunun kirlenmesi önlenmiştir. Otel 28, 29 ve 30 eski üniforma ve çarşaf gibi tekstil ürünlerini kilim dokutarak değerlendirirken, Otel 74 ise kullanılmış ve yıpranmış tekstil ürünlerini temizlik malzemesi olarak kullanmaktadır. Kimyasal kullanımı ile ilgili Otel 8 ve 10 bahçe bakımında biyolojik mücadele yöntemlerine öncelik vermektedir. Otel 73 ise hizmet süreçlerinde zararlı madde kullanımını azaltmakta ve daha az kirletici özelliği bulunan maddeleri tercih etmektedir.

Yiyecek-içecek ile ilgili yapılan uygulamalar incelendiğinde, az sayıda işletmenin konu ile ilgili bilgilendirme yaptığı görülmektedir. Buna göre, işletmeler organik tarımla üretilen yiyecek ve içecekler ile bölgenin ve yerel halkın kalkındırılması amacıyla yerel tedarikçilerden satın alınan yiyecek ve içecek ürünlerini kullanmaktadır. Otel 46, 48, 92, 93, 97 ve 103 bazı ürünleri çevreye duyarlı bir şekilde kendileri üretirken, Otel 61 de tüm yıl boyunca mutfak ihtiyacını karşılayacak şekilde sahip olduğu tarım arazilerinde organik tarım yapmaktadır. Otel 21, 26, 31, 64, 82 ve 83 kontrollü ve sertifikalı biçimde kendi arazilerinde kendi markaları altında yetiştirdiği ürünler ile organik tarım yapmaktadır. Otel 86 , organik sertifikalı buğdaylardan elde edilen unla farklı çeşitlerde ekmek ve çeşitli meyvelerden reçel yapım atölyelerine sahiptir. Otel 4, misafirlerinin istekleri doğrultusunda fabrikasyon şaraplar yerine ev yapımı şaraplar servis etmekte ve Otel 35 kahvaltı dahil olmak üzere en az iki adet yerel gıda ürününü yemeklerde sunmaktadır. Otel 47 ve 65 de satın alma sürecinde organik ve yerel gıda ürünlerini tercih etmektedir.

Çevreye duyarlılık kapsamında yapılan diğer uygulamalar arasında yerel tedarik, sera gazı yaymayan araç kullanımı, bisiklet hizmeti, elektronik yazışma ve çevre anketi gibi örnekler yer almaktadır. Araştırmada çevreyle ilgili diğer uygulamaları hakkında bilgi veren konaklama işletmesi sayısı azdır. Otel 14, tedarik ettiği ürünlerin \%95 gibi çok büyük bir kısmını yerel pazardan sağlamaktadır. Otel 98 , satın almalarında öncelikli olarak yerel üreticileri seçerek ulaşım esnasında düşük enerji harcanmasına ve daha az sera gazı salınımına destek vermektedir. Otel 40 da tedariklerini yakın çevreden yaparak hem yerele destek vermekte hem de karbon emisyon oranını en aza indirgemeyi hedeflemektedir. Otel 28, 29, 30, 35, 67, 98 ve 104 misafirlerine toplu taşımadan nasıl faydalanacaklarını anlatıp toplu taşımayı özendirmekte ve kısa mesafelerde bisiklet hizmeti sunarak karbondioksit emisyon oranının artmasını engellemeye çalışmaktadır. Otel 2, kağıt tüketimini en aza indirmek için elektronik yazışma sistemi ve e-fatura ile sipariş alımları, değişim ve sipariş düzenlemeleri, masa hesap takipleri, stok kontrolleri gibi özelliklere sahip el terminal sistemlerini kullanmaktadır. Otel 8, 33, 77 ve 90 ise misafirlerin tesisin çevreye duyarlılık çalışmaları hakkında görüşlerini almak ve değerlendirmek gibi amaçlarla çevre anketleri uygulamaktadır.

\section{Tartışma ve Sonuç}

$\mathrm{Bu}$ araştırmada yeşil yıldız belgeli konaklama işletmelerinin büyük çoğunluğunu beş yıldızlı otellerin oluşturduğu ve bu işletmelerin daha çok resort ve zincir oteller olduğu, en fazla Antalya ilinde yer aldığı, bununla birlikte İstanbul, Muğla, İzmir ve Ankara illerinde bulunan yeşil yıldızlı konaklama işletmelerinin çoğunluğu meydana getirdiği görülmüştür. Rahman ve diğerlerinin (2012) Kuzey Amerika'daki oteller üzerine yapmış 
oldukları araştırma ile benzerlik gösteren bu sonuçlara göre; büyük ölçekli oteller küçük ölçekli otellere, zincir oteller ise bağımsız otellere göre çevre duyarlılığı, enerji, elektrik ve su tasarrufu, geri dönüşüm, çevre eğitimi ve atıkların ayrıştırılması gibi konulara daha fazla önem vermektedir. Bu durumun büyük ölçekli konaklama işletmelerinin kapasitelerine oranla daha çok tüketim yapmaları ve daha çok enerjiye intiyaç duymaları sebebiyle maliyetlerini azaltma ve kontrol altına alma eğilimleri, bakanlık tarafından belirlenen kriterleri maddi açıdan daha kolay yerine getirebilmeleri ve farklı turist profillerini ağırlamaları gibi nedenlerden kaynaklandığı söylenebilir. Bununla birlikte zincire bağlı birçok konaklama tesisinin işletme politikaları gereği çevre ile ilgili uygulamalarını merkezi olarak ve daha kolay gerçekleştirebilmeleri yeşil yıldız kriterlerini sağlamada kolaylık yaratmaktadır. Yeşil yıldız belgeli konaklama işletmelerinin çoğunluğunun Antalya'da olmasının en önemli sebebi ise en fazla konaklama tesisinin bu ilde olması olarak açıklanabilir.

Internet aracılığıyla rezervasyonların arttığı ve turistlerin yeşil turizme daha fazla önem vermeye başladığı günümüzde konaklama işletmelerinin çevre ile ilgili uygulamalarını web sitelerinde belirtmesi oldukça önem taşımaktadır. Lee ve diğerleri (2010), yeşil otel imajı yaratmanın daha fazla turisti elde tutmak ve otele çekmek için önemli bir güç olduğunu belirtirken, TUYUP (2016) da tatil planlayanların \%56'sının konaklama işletmelerinin yeşil olup olmadığını detaylı olarak sorguladığını ifade etmektedir. Çevreye duyarlı konaklama işletmesi sayısı her geçen gün hızla artmasına rağmen bu çalışmada elde edilen sonuçlara göre işletmelerin yarısından fazlası web sitelerinde çevre yönetimi ile ilgili uygulamaları hakkında bilgi vermemektedir. SezenDoğancili ve Akbulut (2015) da araştırmalarında yeşil yıldız belgeli konaklama işletmelerinin birçoğunun tanıtımlarında bu uygulamalara ait bilgileri yeterince kullanmadıkları sonucuna ulaşmıştır. Bu durumun yıllara göre farklılık göstermemesi yönetimsel yetersizliklerden, işletmelerinin çevre uygulamalarını bir pazarlama unsuru olarak kullanabileceklerinin farkında olmamalarından ya da reklam ve tanıtımı daha çok seyahat acenteleri üzerinden yürütmelerinden kaynaklandığı düşünülmektedir. Öte yandan bağımsız otel işletmelerinin web sitesi yönetimi konusunda kendi birimlerinin olmaması ve bu tanıtım için ayrıca bir bütçe ayırmak istememeleri dolayısı ile güncelliklerini koruyamamaları da çevre ile ilgili uygulamalarını duyurmamalarının nedenleri arasında sayılabilir.

Çevre dostu konaklama işletmelerinin sahip olduğu ödül ve sertifikalar tüketicilerin satın alma davranışını en fazla etkileyen unsurlar arasında yer almaktadır (Manaktola ve Jauhari, 2007; Millar ve Baloglu, 2011; Sezen-Doğancili ve Akbulut; 2015). Araştırma dahilindeki yeşil yıldız belgeli konaklama işletmelerinin web sitelerinde en fazla yer verilen çevre unsuru ödül ve sertifikalardır. Ancak buna rağmen ödül ve sertifikaları ile ilgili hiçbir bilgilendirme yapmayan işletmelerin sayısı daha fazladır. Konaklama işletmelerinin emek, zaman ve para harcayarak elde ettikleri ödül ve sertifikaların daha fazla tanıtımını yapmaları için farkındalıklarının arttırılması gerekmektedir. Kültür ve Turizm Bakanlığı'nın yeşil yıldız kriterlerine tanıtım konusunda ekleyebileceği bir madde işletmelerin bu konudaki eksiğini gidermeye yarayabilir. Öte yandan çevre ile ilgili yapılan uygulamaların duyurulması tüketicilerin de konu ile ilgili bilgi sahibi olmalarına ve yapılan çalışmaların sürdürülebilirliğine katkı sağlayacaktır.

Çevre ile ilgili örgütler ve sivil toplum kuruluşları ile çevreye duyarlı turist profilinin artan baskıları, işletmeleri çevre dostu olmaları konusunda etkilemekte ve birçok işletme bu doğrultuda çevre politikaları geliştirmektedir (Chan ve Wong, 2006). Konaklama işletmeleri çevreyi korumanın hem kendi varlıklarını sürdürmeleri yolunda önemli bir etken olduğunu kavramakta hem de çevreye duyarlı uygulamaları kullanarak maliyetlerini en aza indirgemeyi hedeflemektedir. Kültür ve Turizm Bakanlığı'nın yeşil 
yıldız belgeli konaklama işletmelerine uyguladığı \%30 elektrik indirimi (TUYUP, 2016) de bu belgeye sahip olmak isteyen işletmelerin sayısında artışa neden olmaktadır. Bu araştırmada yeşil yıldız belgeli konaklama işletmelerinin büyük çoğunluğunun bu belgeyi web sitelerinde belirtmediği tespit edilmiştir. Bu durumun sebeplerinden birinin konaklama işletmelerinin web sitelerini güncellememesi, diğerinin ise işletmelerin sadece bu indirimden faydalanmak istemeleri olduğu düşünülmektedir. Akdağ ve diğerlerinin (2014) de belirttiği gibi işletmelerin yeşil yıldızı doğrudan gelir sağlayan bir sertifika olarak görmekten ziyade sürdürülebilir bir rekabet avantajı elde etmenin bir aracı olarak görmeleri gerekmektedir.

Turist talebini karşılamak ve turizmin gelişimini sağlamak doğal ve yapay kaynakların korunmasına ve uygunluğuna bağlıdır (Briassoulis ve Van der Straaten, 2000). Konaklama işletmelerinin gelişimi ve refahı için de doğal kaynakların sürdürebilir olması gerekmektedir (Bohdanowicz, 2005). TUYUP (2016) tarafından yapılan bir araştırmada, iş için seyahat edenlerin \%95'inin konaklama işletmelerinin yeşil olması gerektiğini belirttiği ortaya konmuştur. Bu çalışmada ise yeşil yıldız belgeli, yoğunlukla iş amaçlı konaklayanlar tarafından tercih edildiği söylenebilecek, şehir otellerinin sayısının ve bu işletmelere ait web sitelerinde yer alan çevreye duyarlı uygulama bilgilerinin oldukça az olduğu görülmektedir. Örneğin bir zincir otel işletmesi çoğunluğu iş için kullanılan şehir otellerinde çevre ile ilgili hiçbir uygulamasına yer vermezken, sahip olduğu tek resort otelin web sitesinde tüm uygulamalarını detaylı biçimde aktarmaktadır. Çevre ile ilgili artan duyarlılığa bağı olarak yeşil yıldız belgeli tüm konaklama işletmelerinin öncelikle bir çevre politikası belirlemesi ve bu politika bağlamında yaptığı uygulamaları bir pazarlama aracı olarak daha fazla duyurması önerilmektedir. Web sitelerinde çevreye duyarlı uygulamalarına yer veren işletmelerin bu kanalı daha etkin ve verimli şekilde kullanması farkındalığı arttırmak açısından önem taşımaktadır.

Araştırmada işletmelerin web siteleri analiz edildiğinden yöneticilerin konu ile ilgili bakış açıları, çevre uygulamalarının hangi amaçlarla yapıldığı ve tanıtımda bu uygulamalara yeterince yer verilmemesinin nedenleri irdelenememiştir. Yeşil yıldız belgeli konaklama işletmesi sayısının devamlı artıyor olması da çalışmanın güncelliğinin korunmasında zorluklar yaratmıştır. Bu araştırma, Kültür ve Turizm Bakanlığı'nın 31.05.2016 tarihli listesi temel alınarak hazırlanmıştır ancak bu listede yer alan konaklama işletmelerinin sayısı her güncellemede artmaktadır. Gelecek çalışmalarda, en güncel listeler kullanılarak konaklama işletmelerinin çevreye duyarlı uygulamaları ile profilleri karşılaştırmalı olarak ele alınabilir. İşletme yöneticileri ile yapılacak görüşmeler konaklama işletmelerinin çevreye duyarlı uygulamalarının tanıtımında nasıl bir politika izlendiğinin ve yetersiz tanıtımın nedenlerinin aydınlatılmasında faydalı olacaktır.

\section{Kaynakça}

Akdağ, G., Güler. O., Demirtaş, O., Dalgıç, A. ve Yeşilyurt, C. (2014), 'Turizm ve Çevre İlişkisi: Türkiye'deki Yeşil Otellerin Gözünden Yeşil Otelcilik Uygulamalarının Getirileri', Türkiye Coğrafyacılar Derneği Uluslararası Kongresi, 4-6 Haziran 2014, Muğla, ss. 258-267.

Atay, L. ve Dilek, S.E. (2013), 'Konaklama İşletmelerinde Yeşil Pazarlama Uygulamaları: Ibis Otel Örneği', Süleyman Demirel Üniversitesi İktisadi ve Idari Bilimler Fakültesi Dergisi, 18(1), ss. 203-219.

Atay, L., Dilek, S.E. ve Yıldırım, H.M. (2013), 'Green Hotel Management and Green Star Practice: A Case Study of Best Western President Istanbul Hotel', SOID, 10(1), ss. 71-85. 
Ayaş, N. (2007), 'Çevresel Sürdürülebilir Turizm Gelişmesi', Iktisadi ve Idari Bilimler Fakültesi Dergisi, 9(1), ss. 1-11.

Aykan E. ve Sevim B. (2013), 'Konaklama İşletmelerinde Çevre Yönetimi Uygulamaları ve Algılanan Kurumsal İtibar Üzerine Etkisi: Kayseri ve Nevşehir Otelleri Üzerinde Bir Araştırma', İşletme Araştırmaları Dergisi, 5(3), ss. 93-113.

Berry, M.A ve Randinelli, D.A. (1998), 'Proactive Corporate Environmental Management: A New Industrial Revolution', Academy of Management Executive, 12(2), 38-50.

Bohdanowicz, P. (2005), 'European Hoteliers' Environmental Attitudes Greening The Business', Cornell Hotel and Restaurant Administration Quarterly, 46(2), ss. 188-204.

Borg, J. (1999), 'Sustainable Tourism and European Natural and Cultural Heritage', Tourism and Environment: Natural, Cultural and Socio-Economic Challenges of Sustainable Tourism Proceedings, 9-11 Eylül 1999, Riga, Latvia, ss. 43-48.

Bramwell, B. ve Alletorp, L. (2001), 'Attitudes in the Danish Tourism Industry to the Roles of Business and Government in Sustainable Tourism', International Journal of Tourism Research, 3(2), ss. 91-103.

Briassoulis, H. ve Van der Straaten, J. (2000), 'Tourism and The Environment: An Overview', İçinde H. Briassoulis ve J. Van der Straaten (Editörler), Tourism and The Environment: Regional, Economic, Cultural and Policy Issues, ss. 1-19, Dordrecht: Springer Science+Business Media.

Camilleri, M. (2014), 'Advancing the sustainable Tourism Agenda Through Strategic CSR Perspectives', Tourism Planning \& Development, 11(1), ss. 42-56.

Chan, E.S.W. ve Wong, S.C.K. (2006), 'Motivations for ISO 14001 in the Hotel Industry', Tourism Management, 27, ss. 481-492.

Creswell, J.W. (2016), Nitel Araştırma Yöntemleri, (M. Bütün ve S. B. Demir, Çeviri), Ankara: Siyasal Kitabevi.

Erdogan, N. ve Baris, E. (2007), 'Environmental Protection Programs and Conservation Practices of Hotels in Ankara, Turkey', Tourism Management, 28, ss. 604-614.

Eren, D. ve Yılmaz, İ. (2008), 'Otel İşletmelerinde Yeşil Pazarlama Uygulamaları: Nevşehir Örneği', 13. Pazarlama Kongresi, 25-29 Ekim 2008, Nevşehir, ss. 290300.

Esparon, M., Gyuris, E., ve Stoeckl, N. (2014), 'Does ECO Certification Deliver Benefits? An Empirical İnvestigation of Visitors' Perceptions of the Importance of ECO Certification's Attributes and of Operators' Performance', Journal of Sustainable Tourism, 22(1), ss. 148-169.

Font, X. (2002), 'Environmental Certification in Tourism and Hospitality: Progress, Process and Prospects', Tourism Management, 23(3), ss. 197-205.

Font, X. ve Buckley, R. (2001), Tourism Ecolabelling: Certification and Promotion of Sustainable Management, Wallingford: CAB International.

Foster, S.T., Sampson, S.E. ve Dunn, S.C. (2000), 'The Impact of Customer Contact on Environmental Initiatives for Service Firms', International Journal of Operations\&Production Management, 20(2), ss. 187-203.

Gil M.J.Á., Jiménez, J.B. ve Lorente J.J.C. (2001), 'An Analysis of Environmental Management, Organizational Context and Performance of Spanish Hotels', Omega, 29(6), ss. 457-471.

Giritlioğlu, İ. ve Güzel, M.O. (2015), 'Otel işletmelerinde Yeşil Yıldız Uygulamaları: Gaziantep ve Hatay Bölgesinde Bir Araştırma', Uluslararası Sosyal Araştırmalar Dergisi, 8(40), ss. 889-904.

Goodwin, H. (2014), 'Responsible Tourism an the Green Economy', İçinde T. Delacy, M. Jiang, G. Lipman ve S. Vorster (Editörler), Green Growth and Travelism, 
Concept, Policy and Practice for Sustainable Tourism, ss. 133-144, London and Newyork: Routledge.

Gössling, S. (1999), 'Ecotourism: A Means to Safeguard Biodiversity and Ecosystem Functions?', Ecological Economics, 29, ss. 303-320.

Gössling, S. ve Buckley, R. (2016), 'Carbon Labels in Tourism: Persuasive Communication?', Journal of Cleaner Production, 111, ss. 358-369.

GreenGlobe (2016), 'GreenGlobe', http://greenglobe.com/about/, (24.12.2016).

Green Key (2016), 'Our programme', http://www.greenkey.global/our-programme/, (24.12.2016).

Green Tourism (2016), 'We are the Go-To Standard for Sustainability', http://www.green-tourism.com/about/, (24.12.2016).

Greening Hotels (2016), 'Greening Hotels', http://www.yesillenenoteller.com/, (17.08.2017).

Guba, E.G. (1981), 'Criteria for Assessing The Trustworthiness of Naturalistic Inquiries, Educational Communication and Technology', A Journal of Theory, Research, and Development, 29(2), ss. 75-91.

Ham, S. ve Han, H. (2013), 'Role of Perceived Fit With Hotels' Green Practices in the Formation of Customer Loyalty: Impact of Environmental Concerns', Asia Pacific Journal of Tourism Research, 18(7), ss. 731-748.

Han, H., Hsu, L.T.J. ve Lee, J.S. (2009), 'Empirical Investigation of The Roles of Attitudes Toward Green Behaviors, Overall Image, Gender, and Age in Hotel Customers' Eco-Friendly Decision-Making Process', International Journal of Hospitality Management, 28(4), ss. 519-528.

ITB (2016), 'ITB World Travel Trends Report 2015/2016', http://www.itbberlin.de/media/itbk/itbk dl all/itbk dl all itbkongress/itbk dl all itbkongress it bkongress365/itbk_dl_all_itbkongress_itbkongress365_itblibrary/itbk_dl_all_itbk ongress_itbkongress365_itblibrary_studien/ITB_World_Travel_Trends_Report_2 015_2016.pdf, (24.12.2016).

Jarvis, N., Weeden, C. ve Simcock, N. (2010), 'The Benefits and Challenges of Sustainable Tourism Certification: A Case Study of the Green Tourism Business Scheme in the West of England.', Journal of Hospitality and Tourism Management, 17(1), ss. 83-93.

Jeong, M., Oh, H. ve Gregoire M. (2003), 'Conceptualizing Web Site Quality and Its Consequences in The Lodging Industry', Hospitality Management, 22, ss. 161175.

Johri, M.L. ve Sahasakmontri, K. (1998), 'Green Marketing of Cosmetics and Toiletries in Thailand', Journal of Consumer Marketing, 15(3), ss. 265-281.

Kahraman, N. ve Türkay, O. (2014), Turizm ve Çevre, Ankara: Detay Yayıncılık.

KTB(a) (Kültür ve Turizm Bakanlığı) (2016), 'Mavi Bayrak Hakkında Genel Bilgiler', http://www.ktbyatirimisletmeler.gov.tr/TR,11570/mavi-bayrak-hakkinda-genelbilgiler.html, (24.12.2016).

KTB(b) (2016), 'Çevreye Duyarlılık Kampanyası (Yeşil Yıldız)', http://yigm.kulturturizm.gov.tr/TR,11596/cevreye-duyarlilik-kampanyasi-yesilyildiz.html, (24.12.2016).

Lee, J.S., Hsu, L.T., Han, H. ve Kim, Y. (2010), 'Understanding How Consumers View Green Hotels: How a Hotel's Green Image Can Influence Behavioural Intentions', Journal of Sustainable Tourism, 18(7), ss. 901-914.

LEED (2016), 'About LEED', http://www.usgbc.org/leed, (24.12.2016).

Machaira, A., Lampropoulos T. ve Zentelis, P. (2012), 'Green Hotelling. A Feasibility Study in the Hellenic Island of Skyros', FIG Working Week, 6-10 May 2012, Rome, Italy. 
Manaktola, K. ve Jauhari, V. (2007), 'Exploring Consumer Attitude and Behaviour Towards Green Practices in The Lodging Industry in India', International Journal of Contemporary Hospitality Management, 19(5), ss. 364-377.

Merriam S.B. (2013), Nitel Araştırma, (S. Turan, Çeviri), Ankara: Nobel Akademik Yayıncilık.

Mihalič, T. (2000), 'Environmental Management of a Tourist Destination: A Factor of Tourism Competitiveness', Tourism Management, 21(1), ss. 65-78.

Millar, M. ve Baloglu, S. (2011), 'Hotel Guests' Preferences for Green Guest Room Attributes', Cornell Hospitality Quarterly, 52(3), ss. 302-311.

Rahman, I., Reynolds, D. ve Svaren, S. (2012), "How "Green" are North American hotels? An Exploration of Low-Cost Adoption Practices', International Journal of Hospitality Management, 31(3), ss. 720-727.

Sasidharan, V., Sirakaya, E. ve Kerstetter, D. (2002), 'Developing Countries and Tourism Ecolabels', Tourism Management, 23(2), ss. 161-174.

Seyhan, G. ve Yılmaz, B.S. (2010), 'Sürdürülebilir Turizm Kapsamında Konaklama İşletmelerinde Yeşil Pazarlama: Calista Luxury Resort Hotel', İ̧letme Fakültesi Dergisi, 11(1), ss.51-74.

Sezen Doğancili, O. ve Akbulut, B.A. (2015), 'Yeşil Yıldız Çevre Etiketine Sahip Otellerin Web Sitelerinde Yeşil Pazarlamayı Kullanmalarına İlişkin İçerik Analizi', 16. Ulusal Turizm Kongresi, Çanakkale Onsekiz Mart Üniversitesi, 12-15 Kasım 2015, ss. 402-417.

Standart Kalite (2016), 'ISO 14001'in Tarihçesi', http://www.standartkalite.com/iso14001_tarihcesi.hltm, (24.12.2016).

Şanlıöz Özgen, H.K., Dilek, S.E., Türksoy, S.S. ve Kaygalak Çelebi, S. (2016), Sürdürülebilir Turizm Yönetimi, N. Koçak (Editör), Ankara: Detay Yayıncılık.

Toth, R. (2002), 'Exploring the Concepts Underlying Certification', İçinde M. Honey (Editör), Ecotourism and Certification Setting Standards in Practice, ss. 73-102, Washington: Island Press.

Travelife (2016), 'What is Travelife?', http://www.travelife.org/Hotels/What_is_TL.asp?p=2, (24.12.2016).

TUI (2016), 'TUI Umwelt Champion\&EcoResort: Umweltschutz im Urlaub', http://www.tui.com/umweltschutz-im-urlaub/, (24.12.2016).

Turizm Dünyası (2008), 'Beyaz Bir Yıldız', http://www.turizmdunyasi.com.tr/arsiv/yazi/beyaz-bir-yyldyz, (24.12.2016).

TUYUP (2016), 'Yeşil Yıldız Bilgi Broşürü', http://tuyup.turizm.gov.tr/Yayinlar/Ye\%C5\%9Fil\%20Y\%C4\%B1ld\%C4\%B1z\%20 Bilgi\%20Bro\%C5\%9F\%C3\%BCr\%C3\%BC.pdf, (24.12.2016).

TÜRÇEV (2016), 'Yeşil Anahtar Programı ve Tarihçesi', http://www.turcev.org.tr/icerikDetay.aspx?icerik_id=15, (24.12.2016).

TripAdvisor (2012), 'TripAdvisor Survey Reveals Travelers Growing Greener', https://tripadvisor.mediaroom.com/2012-04-19-TripAdvisor-Survey-RevealsTravelers-Growing-Greener, (18.08.2017).

UNWTO. (2015a), 'Global Report on Cultural Routes and Itineraries', Affiliate Members Global Reports, Volume Twelve.

Usta, Ö. (2009), Turizm: Genel ve Yapısal Yaklaşım, Ankara: Detay Yayıncılık.

Watkins, E. (1994), 'Do Guests Want Green Hotels?', Lodging Hospitality, 50(4), ss. 70-72.

Yıldırım, A. ve Şimşek, H. (2013), Sosyal Bilimlerde Nitel Araştırma Yöntemleri. Ankara: Seçkin Yayıncılık.

Yıldırım Saçılık, M. ve Çevik, S. (2014), 'Çevreye Duyarlı Otelcilik Kapsamında Yeşil Yıldız Uygulaması: Antakya Güngör Ottoman Palace Örneği', $9^{\text {th }}$ International Conference: New Perspectives in Tourism and Hospitality, 25-27 Eylül 2014, Balıkesir, ss. 404-414. 
Yıldız, S.B. ve Kılıç, S.N. (2016), 'Alman Turistlerin Çevre Bilinci ve Çevre Dostu Otel (Yeşil Otel) Algısının Davranışsal Niyetleri Üzerindeki Etkisi', Uluslararası Sosyal Araştırmalar Dergisi, 9 (43), ss. 2614-2623.

Yılmaz, B.S. ve Yumuk, Y. (2013), 'Türk Turizm Pazarında Çevreye Duyarlı Bir Eğilim: "Yeşil Yıldız" Uygulamaları ve "Yeşil Yıldız" Sahibi Otel İşletmeleri Üzerine Bir Değerlendirme', 14. Ulusal Turizm Kongresi, 5-8 Aralık 2013, Kayseri, ss. 12881300. 